\title{
Subdiaphragmatic Abscess
}

National Cancer Institute

\section{Source}

National Cancer Institute. Subdiaphragmatic Abscess. NCI Thesaurus. Code C128327.

An abscess that is located in the anatomical space between the diaphrag $\mathrm{m}$ and the liver and/or spleen. 